DOI: $10.19195 / 0137-1134.114 .24$

\author{
MIROSŁAW STEC \\ Uniwersytet Jagielloński \\ miroslaw.stec@uj.edu.pl
}

\title{
WPŁYW NOWYCH ZASAD ZARZĄDZANIA MIENIEM PAŃSTWOWYM NA KSZTAŁT RADY NADZORCZEJ I ZARZĄDU SPÓŁKI KOMUNALNEJ
}

\begin{abstract}
Abstrakt: W ustawie o zasadach zarządzania mieniem państwowym, uchwalonej w 2016 roku, dokonano gruntowanego przekształcenia całego systemu gospodarowania mieniem państwowym, co objęło także jego aspekty funkcjonalne oraz strukturalno-organizacyjne. W ramach tej reformy znowelizowane zostały też niektóre przepisy ustawy o gospodarce komunalnej, co jest zrozumiałe ze względu na przynależność obu rodzajów mienia (państwowe i komunalne) do jednej kategorii mienia publicznego. W niniejszym artykule została udzielona odpowiedź na pytanie: jakie konsekwencje dla sektora samorządowego i występujących w nim podmiotów gospodarczych (przedsiębiorców działających na bazie własności komunalnej) niosą wprowadzone zmiany odnoszące się do statusu, składu, powoływania i funkcjonowania rady nadzorczej i zarządu spółki komunalnej?
\end{abstract}

Słowa kluczowe: mienie państwowe, mienie komunalne, gospodarka komunalna, spółka komunalna, rada nadzorcza, zarząd

1. 16 grudnia 2016 roku uchwalona została ustawa o zasadach zarządzania mieniem państwowym ${ }^{1}$ (dalej: uzzmp), która — na podstawie ustawy z tego samego dnia Przepisy wprowadzające ustawę o zasadach zarządzania mieniem państwowym $^{2}$ (dalej: upwuzzmp) — weszła w życie 1 stycznia 2017 roku. Zastąpiła ona, uchwaloną w 1996 roku, ustawę o zasadach wykonywania uprawnień przysługujących Skarbowi Państwa ${ }^{3}$ (dalej: uzwupSP). Uchwalony w 2016 roku akt dokonał fundamentalnego przekształcenia całego systemu gospodarowania mieniem państwowym i stanowi jeden z elementów wieloaspektowej reformy sfery wykonywania uprawnień właścicielskich Skarbu Państwa. W sposób znaczący nie tylko zostały zmienione zasady zarządzania mieniem państwowym (na co wskazywałby ty tuł ustawy), lecz także dokonano głębokich zmian systemowych, w tym również

1 Tekst jedn. Dz.U. z 2018 r. poz. 1182.

2 Dz.U. poz. 2260.

3 Ustawa z dnia 8 sierpnia 1996 r. (tekst jedn. Dz.U. z 2016 r. poz. 154 z późn. zm.). 
natury strukturalno-organizacyjnej. Zasadniczym celem tej ustawy — zdaniem projektodawcy — było podniesienie jakości zarządzania mieniem państwowym, w tym nadzoru właścicielskiego, poprzez zmianę funkcjonowania dotychczasowego modelu i położenie głównego akcentu na efektywne gospodarowanie przez państwo posiadanym mieniem w celu budowania jego trwałej wartości, a także na jego zabezpieczenie przed możliwymi nadużyciami ${ }^{4}$. Istotne założenia nowego systemu zarządzania mieniem państwowym, wskazane w uzasadnieniu do projektu ustawy, polegają w szczególności na:

1. określeniu wspólnych dla wszystkich stationes fisci zasad zarządzania mieniem państwowym z podkreśleniem, że mienie to służy przede wszystkim realizacji zadań publicznych, a gospodarowanie nim winno następować w sposób zgodny z zasadami prawidłowej gospodarki oraz z zachowaniem należytej staranności;

2. precyzyjnym wskazaniu, który organ administracji jest właściwy do gospodarowania poszczególnymi składnikami mienia państwowego, co wiąże się ze zniesieniem działu administracji rządowej „Skarb Państwa” i likwidacją Ministerstwa Skarbu Państwa oraz - w konsekwencji — przesądzeniem, które organy administracji rządowej i w jakim zakresie będą wykonywać uprawnienia ze sfery dominium;

3. utworzeniu szczególnego organu — rady do spraw spółek z udziałem Skarbu Państwa i państwowych osób prawnych — jako ciała doradczego, zapewniającego Prezesowi Rady Ministrów kompleksowe i profesjonalne wsparcie w zakresie koordynacji nadzoru właścicielskiego; do jej zadań będzie należało również opiniowanie kandydatów do organów spółek z udziałem Skarbu Państwa oraz państwowych osób prawnych;

4. określeniu wymagań dla członków organów nadzorczych spółek z udziałem Skarbu Państwa oraz państwowych osób prawnych;

5. zasadniczej zmianie modelu zbywania akcji i udziałów Skarbu Państwa poprzez rezygnację z tak zwanej prywatyzacji bezpośredniej, a — w konsekwencji - rezygnację ze stosowania w ogóle pojęcia ,prywatyzacja” (co przejawiło się między innymi w zmianie tytułu ustawy z 1996 roku z „o komercjalizacji i prywatyzacji” [dalej: ukp] na „o komercjalizacji i niektórych uprawnieniach pracowników" [dalej: uknup]) ${ }^{6}$.

2. Celem niniejszego artykułu nie jest jednak prezentacja i ocena założeń czy konkretnych rozwiązań normatywnych przewidzianych w tej ustawie, lecz odpowiedź na pytanie: jakie konsekwencje, naturalnie nie wszystkie, a tylko wybrane odnoszące się do statusu, składu i funkcjonowania rady nadzorczej i zarządu spółki komunalnej, niesie ona dla sektora samorządowego i występujących w nim

\footnotetext{
4 Zob. uzasadnienie do rządowego projektu ustawy, druk nr 1053 z 2016 r., sejm.gov.pl.

5 Ustawa z dnia 30 sierpnia 1996 r. (tekst jedn. Dz.U. z 2017 r. poz. 1055).

${ }^{6}$ Zob. uzasadnienie do rządowego projektu ustawy, druk nr 1053 z 2016 r.
} 
podmiotów gospodarczych — przedsiębiorców działających na podstawie własności komunalnej? Nie jest tym bardziej zadaniem tego opracowania odpowiedź na ogólne pytanie o dopuszczalność i zakres wykorzystywania różnych typów form organizacyjno-prawnych, a zwłaszcza spółek handlowych, przez jednostki samorządu terytorialnego (dalej: jst) przy wypełnianiu ich zadań publicznych ${ }^{7}$.

3. Bliskie związki pomiędzy oboma sektorami - państwowym i komunalnym — w sferze prowadzenia działalności gospodarczej wynikają nie tylko z faktu publicznoprawnego statusu właścicieli tego mienia (Skarbu Państwa i jst) i ujmowania go $-\mathrm{w}$ ujęciu teoretycznym $-\mathrm{w}$ jednej kategorii mienia publicznego ${ }^{8}$, lecz także z funkcjonalnego powiązania opartego na podstawie normatywnej. Otóż podstawowa dla prowadzenia działalności gospodarczej przez samorząd terytorialny ustawa o gospodarce komunalnej z 1996 roku $^{9}$ (dalej: ugk) w wielu artykułach odsyłała do innych ustaw, w tym - poza ustrojowymi (o samorządzie gminnym, dalej: usg; samorządzie powiatowym, dalej: usp; samorządzie województwa, dalej: usw) - przede wszystkim do ukp. Dlatego w upwuzzmp w art. 15 dokonuje się nowelizacji ugk, polegającej nie tylko na zastąpieniu uknup, występującej w jej trzech przepisach, uzzmp, lecz także na wprowadzeniu nowych rozwiązań prawnych. Jak zatem obecnie wygląda normatywny kształt zmienionych konstrukcji w zakresie prowadzenia działalności gospodarczej przez jednostki samorządu terytorialnego?

4. Warto przypomnieć, że ugk została uchwalona jako ostatnia z trzyelementowego cyklu ustaw, przyjętych w 1996 roku, dotyczących gospodarowania mieniem publicznym, obejmującego również dwie przytoczone ustawy, to jest uzwupSP i ukp (obecna nazwa uknup).

Charakteryzując zasadniczą relację między ugk a pozostałymi dwiema ustawami, można stwierdzić, że od samego początku ugk odznaczała się daleko idącą samodzielnością w unormowaniu kwestii objętych zakresem tej ustawy, co przejawiło się $\mathrm{w}$ prawie całkowitym pominięciu odesłań (poza art. 20 ust. $1 \mathrm{w}$ wersji pierwotnej oraz art. 10a ust. 5 i art. 12 ust. 1-2 po nowelizacji z 2003 roku, w których przewidziano odpowiednie stosowanie ukp). Dopiero uchwalenie uzzmp i przeniesienie do niej wielu unormowań, o zmienionej istotnie treści, dotąd znajdujących się w ukp, spowodowało, że w znowelizowanym tekście ugk można znaleźć odwołania zarówno do uzzmp, jak i uknup. Było to wynikiem przyjęcia fundamentalnej tezy o odrębności i samodzielności samorządu terytorialnego nie tylko

7 Wśród wielu pozycji w tym zakresie zob. zwłaszcza L. Kieres, [w:] System Prawa Administracyjnego, t. 8A. J. Grabowski, L. Kieres, A. Walaszek-Pyzioł, Publiczne prawo gospodarcze, Warszawa 2013, s. 97 n. i przytoczona tam literatura.

8 Szerzej zob. A. Stelmachowski, [w:] System Prawa Prywatnego, t. 3. Prawo rzeczowe, red. E. Gniewek, Warszawa 2013, s. 303 n.; A. Doliwa, Osobowość prawna jednostek samorzadu terytorialnego, Warszawa 2012, s. $331 \mathrm{n}$.

${ }^{9}$ Ustawa z dnia 20 grudnia 1996 r. (tekst jedn. Dz.U. z 2016 r. poz. 573 z późn. zm.). 
co do ustrojowego jego kształtu, lecz także w sferze działalności gospodarczej, czego rezultatem, a zarazem dowodem, jest właśnie uchwalenie odrębnej ustawy dotyczącej wyłącznie gospodarki samorządowej określanej mianem komunalnej.

Objęła ona swym zakresem kwestie zasad i form organizacyjno-prawnych prowadzenia tej gospodarki, przesądzając treść tych zasad i zakres możliwych do wykorzystania normatywnych rodzajów podmiotów gospodarczych lub innych sposobów wykonywania samorządowych zadań publicznych. Dlatego w strukturze tego aktu prawnego (niezmienionej od chwili jego uchwalenia) wyraźnie wydzielono rozdziały traktujące o poszczególnych aspektach gospodarki komunalnej. Podstawowe reguły i postaci wykonywania zadań w sferze samorządowej unormowane zostały w rozdziale 1 (Przepisy ogólne), natomiast kolejne poświęcone zostały poszczególnym formom prowadzenia działalności gospodarczej przez jst. W rozdziale 2 przesądza się natomiast dopuszczalność wykorzystywania w celu realizacji zadań samorządowych formę samorządowego zakładu budżetowego publicznoprawnego podmiotu działającego $\mathrm{w}$ ramach osobowości prywatnoprawnej jednostki samorządu terytorialnego tworzącej ten zakład i prowadzącego gospodarkę finansową na zasadach określonych w ustawie o finansach publicznych ${ }^{10}$. Z kolei rozdział 3 przewiduje możliwość wykorzystywania przez jst konstrukcji spółek prawa handlowego, przy czym wyraźnie stwierdza się dopuszczalność tworzenia spółek kapitałowych (z ograniczoną odpowiedzialnością i akcyjnych) oraz spółek komandytowej i komandytowo-akcyjnej w zakresie przewidzianym w ustawie o partnerstwie publiczno-prywatnym ${ }^{11}$. Oznacza to niemożność posługiwania się przez samorząd terytorialny konstrukcją spółki cywilnej i głównej handlowej spółki osobowej — spółki jawnej. Tym samym podstawowe znaczenie dla regulacji kwestii ustrojowych i funkcjonowania tych spółek mają przepisy kodeksu spółek handlowych ${ }^{12}$ (dalej: ksh) w zakresie sprecyzowanym w ugk, a także przepisy uzzmp, co przesądzają znowelizowane w upwuzzmp przepisy ugk. Wreszcie w rozdziale 4, szczególnie istotnym w chwili uchwalania ustawy, a dziś mającym walor jedynie historyczny, zawarte zostały przepisy o obligatoryjnym (z mocy prawa) przekształceniu istniejących w tymże momencie jeszcze przedsiębiorstw komunalnych, działających na podstawie ustawy o przedsiębiorstwach państwowych ${ }^{13}$, w jednoosobowe spółki gminy, co nastąpiło 1 lipca 1997 roku.

10 Ustawa z dnia 27 sierpnia 2009 r. (tekst jedn. Dz.U. z 2017 r. poz. 2077). Szerzej na jego temat zob. C. Banasiński, M. Kulesza, Ustawa o gospodarce komunalnej. Komentarz, Warszawa 2002, s. 69 n.; W. Gonet, Ustawa o gospodarce komunalnej. Komentarz. Wzory umów i regulaminów, Warszawa 2010, s. 43 n.; J.J. Zięty, Ustawa o gospodarce komunalnej. Komentarz, Warszawa 2012, s. 73 n.; C. Banasiński, K. Jaroszyński, Ustawa o gospodarce komunalnej. Komentarz, Warszawa 2017, s. 116 n.

11 Ustawa z dnia 19 grudnia 2008 r. (tekst jedn. Dz.U. z 2017 r. poz. 1834).

12 Ustawa z dnia 15 września 2000 r. (tekst jedn. Dz.U. z 2017 r. poz. 1577).

13 Ustawa z dnia 25 września 1981 r. (tekst jedn. Dz.U. z 2017 r. poz. 2136 z późn. zm.). 
W konkluzji można zatem stwierdzić, że z punktu widzenia tematu tego opracowania, traktującego o relacjach między regulacją ugk a innymi ustawami normującymi także prowadzenie komunalnej działalności gospodarczej w sferze i za pomocą instrumentów prywatnoprawnych, podstawowe znaczenie mają przepisy zawarte w rozdziale 3 ( $\mathrm{i}$ - choć bez znaczenia praktycznego - w rozdziale 4). Taka konstatacja znajduje pełne potwierdzenie w zakresie zmian w ugk, wprowadzonych w upwuzzmp, które obejmują tylko przepisy zamieszczone w rozdziałach 3-4.

5.1. Pierwszym zagadnieniem, które należy poddać analizie, jest funkcjonowanie organów spółek kapitałowych z udziałem jst, co dotyczy w szczególności rady nadzorczej. O ile w tekście ustawy z 1996 roku kwestia ta nie była uregulowana, a zatem obowiązywały reguły zawarte w kodeksie handlowym (którego przepisy wówczas pozostawały w mocy), o tyle w nowelizacji ugk z roku $2003^{14}$ pojawił się art. 10a, którego treść stanowi lex specialis w stosunku do ksh. W myśl przepisów w nim zawartych (ust. 1) rada nadzorcza działa w każdej spółce z udziałem jst, a więc również w tych, w których ksh pozostawia wspólnikom w pewnym zakresie (co dotyczy spółek z ograniczoną odpowiedzialnością i komandytowo-akcyjnych) swobodę co do powołania tego organu. Nie ma też znaczenia wielkość zaangażowania kapitałowego jst i liczba wspólników ${ }^{15}$. Także w sposób bezwzględnie obowiązujący przesądzony został czas trwania kadencji członków rad nadzorczych w spółkach z większościowym udziałem jst (ust. 3), czyli również jednoosobowych spółek komunalnych, termin ten nie dotyczy natomiast członków rady nadzorczej, także reprezentujących samorząd, oraz spółek z mniejszościowym lub wynoszącym $50 \%$ udziałem jst. Wynosi on trzy lata. Powstaje jednakże pytanie, czy ten — odmienny od unormowania ksh, przewidującego roczną kadencję członka rady nadzorczej, chyba że umowa stanowi inaczej (art. $216 \S 1 \mathrm{ksh}$ w odniesieniu do spółek z o.o.) lub decyzję w tej kwestii pozostawiono statutowi spółki (art. 386 $\S 1$ ksh co do spółek akcyjnych) — czas trwania kadencji dotyczy wszystkich członków rady czy też tylko tych zasiadających z ramienia jst (w spółkach z jej większościowym udziałem).

W literaturze niejednoznacznie interpretuje się ten przepis. Z jednej strony, trafnie się podkreśla ${ }^{16}$, że to unormowanie dotyczy jedynie samorządowych

14 Ustawa z dnia 17 października o zmianie ustawy o gospodarce komunalnej (Dz.U. Nr 199, poz. 1937).

15 Tak M. Szydło, Ustawa o gospodarce komunalnej. Komentarz, Warszawa 2008, s. 433; J.J. Zięty, op. cit., s. 108; G. Góreczny, Rada nadzorcza w spótkach komunalnych - zarys problematyki, „Samorząd Terytorialny” 2010, nr 11, s. 58 n.; C. Banasiński, K. Jaroszyński, op. cit., s. 176. Podobne rozwiązania przewiduje art. 18 ugk dotyczący przekształconych z przedsiębiorstw komunalnych jednoosobowych spółek z udziałem jst.

16 Tak C. Banasiński, K. Jaroszyński, op. cit., s. 179 — aczkolwiek szkoda, że swego poglądu, choćby skrótowo, nie uzasadnili. 
członków rady, co należy uzasadnić zarówno faktem ujęcia tego przepisu w postaci przesądzenia wobec członka rady (a nie jako określenie długości kadencji całej rady), jak i zawężającą metodą wykładni przepisów będących lex specialis, a argumentacja celowościowa pozwala sformułować wniosek, że mniejszościowi wspólnicy mogą kształtować czas trwania kadencji członka rady przez nich desygnowanego zgodnie z przepisami ksh. Z drugiej jednak, prezentowany jest pogląd optujący za literalną wykładnią tego przepisu, choć trudno znaleźć argumenty na rzecz takiego stanowiska ${ }^{17}$.

5.2. Przedstawione kwestie nie są jednak przedmiotem ostatniej nowelizacji ugk. Są natomiast takim zagadnieniem wymagania, jakie członkom rady nadzorczej reprezentującym jst stawia ugk. W ujęciu wprowadzonym w 2003 roku (art. 10a ust. 4) mogli nimi być w zasadzie wszyscy ci, którzy złożyli egzamin w trybie przewidzianym w przepisach ukp (art. 12 ust. 2). Został on szczegółowo określony w rozporządzeniu Rady Ministrów ${ }^{18}$, w myśl którego kandydaci ci winni mieć ukończone studia wyższe (z pewnymi wyjątkami ${ }^{19}$ ) oraz winni zdać egzamin przed komisją wyznaczoną przez ministra właściwego do spraw Skarbu Państwa, co nie dotyczyło osób ze stopniem naukowym doktora prawa lub ekonomii oraz adwokatów, radców prawnych, biegłych rewidentów i doradców inwestycyjnych.

5.3. W aktualnym tekście ustawy ustęp ten został uchylony, natomiast kwestia wymagań wobec kandydatów na członków rad nadzorczych znalazła się w ust. 5, w myśl którego ,podmiot reprezentujący jst lub komunalną osobę prawną w zakresie wykonywania prawa $\mathrm{z}$ akcji przysługujących tym podmiotom, jako kandydata na członka organu nadzorczego wskazuje osobę, która spełnia wymogi, o których mowa w art. 19 ust. 1 uzzmp". Samo brzmienie tego przepisu jest wielce nieprecyzyjne. Po pierwsze, nieprawidłowo i niepotrzebnie użyto terminu ,organ nadzorczy”, chociaż nie ulega wątpliwości, że chodzi tu o radę nadzorczą, a nie inny organ nadzoru (na przykład komisję rewizyjną) ${ }^{20}$. Po drugie, przepis ten, przez użycie zwrotu ,wykonywanie praw z akcji”, a zatem — gdy czytamy go literalnie - wyraźnie został ograniczony do spółek akcyjnych. Spółki z o.o., a także spółki komandytowo-akcyjne nie byłyby objęte jego zakresem. Taka wykładnia całkowicie kłóciłaby się z zasadniczym celem tego fragmentu nowelizacji, który polega na zwiększeniu profesjonalizmu w zarządzaniu spółkami przez członków rady nadzorczej.

Przyczyna wprowadzenia takiego zawężenia jest prosta. W przepisach uzzmp mowa jest tylko o wykonywaniu praw z akcji, gdyż zgodnie z art. 1 pkt 2 tej

17 Tak J.J. Zięty, op. cit., s. 124 — niestety bez uzasadnienia.

18 Rozporządzenie Rady Ministrów z dnia 7 września 2004 r. w sprawie szkoleń i egzaminów dla kandydatów na członków rad nadzorczych spółek, w których Skarb Państwa jest jedynym akcjonariuszem (Dz.U. Nr 198, poz. 2038 z późn. zm.).

$19 \mathrm{~W} \S 3$ tego rozporządzenia wskazano, że nie muszą tego wymogu spełniać kandydaci wybierani przez pracowników, rolników i rybaków.

20 Tak też C. Banasiński, K. Jaroszyński, op. cit., s. 180. 
ustawy przez akcje należy rozumieć też udziały w spółkach z o.o. W nowelizowanych przepisach ugk ani nie odwołano się do przytoczonego przepisu, ani nie wprowadzono jego odpowiednika. Dlatego należy w tym wypadku zastosować dyrektywy wykładni funkcjonalnej, a także systemowej, i przyjać, że mimo pominięcia w tekście wyrażenia ,spółek z o.o.” wymagania określone we wskazanym artykule uzzmp winny być obowiązujące także w relacji do kandydatów do rad nadzorczych spółek z o.o. i spółek komandy towo-akcyjnych ${ }^{21}$.

5.4. Wymogi stawiane kandydatom na członków rad nadzorczych spółek z udziałem Skarbu Państwa zostały bezpośrednio określone w ustawie, a nie jak poprzednio — w rozporządzeniu wykonawczym. W myśl art. 19 ust. 1 uzzmp członkiem rady może zostać osoba mająca pozytywną opinię rady do spraw spółek z udziałem Skarbu Państwa i państwowych osób prawnych, o której mowa w art. 24 pkt 1, spełniająca kumulatywnie następujące warunki:

1. ma wykształcenie wyższe uzyskane w Polsce lub za granicą uznane w Polsce według odrębnych przepisów i nie przewiduje się jakichkolwiek wyjątków umożliwiających osobom bez takiego wykształcenia kandydowanie do organów nadzorczych;

2. ma co najmniej pięcioletni okres zatrudnienia na podstawie umowy o pracę, powołania, wyboru, mianowania, spółdzielczej umowy o pracę lub świadczenia usług na podstawie innej umowy lub wykonywania działalności gospodarczej na własny rachunek;

3. realizuje jeden z warunków:

a) ma stopień naukowy doktora nauk prawnych, ekonomicznych lub technicznych,

b) ma tytuł zawodowy adwokata, radcy prawnego, biegłego rewidenta, doradcy podatkowego, inwestycyjnego lub restrukturyzacyjnego,

c) ukończyła studia Master of Business Administration (MBA),

d) zdobyła renomowane międzynarodowe certyfikaty uznanych instytucji: CFA, CIIA, ACCA, CFF,

e) ma potwierdzenie złożenia egzaminu przed komisją powołaną na podstawie ustawy o narodowych funduszach inwestycyjnych i ich prywatyzacji ${ }^{22}$ lub ukp,

f) złożyła egzamin dla kandydatów na członków organów nadzorczych przed komisją egzaminacyjną wyznaczoną przez Prezesa Rady Ministrów.

Ponieważ ta ostatnia przesłanka (egzamin) będzie odgrywać, tak jak poprzednio, bardzo istotną rolę, a wręcz stanie się najczęstszym sposobem spełnienia warunku umożliwiającego kandydowanie do rady nadzorczej, ustawodawca w samej ustawie określił zasady, organizację i tryb działania tej komisji, a także zakres wiedzy wymaganej na egzaminie (art. 21), podczas gdy w rozporządze-

21 Trafnie to zauważają i uzasadniają C. Banasiński, K. Jaroszyński, op. cit., s. 180.

22 Ustawa z dnia 30 kwietnia 1993 r. (Dz.U. Nr 44, poz. 202 z późn. zm.). 
niu wykonawczym zostały ujęte tylko szczegóły organizacyjne i regulamin jego przeprowadzenia ${ }^{23}$.

5.5. Poza wskazanymi wymogami sformułowanymi w sposób pozytywny $\mathrm{w}$ artykule tym znalazły się też warunki (w zasadzie przeniesione $\mathrm{z}$ art. $13 \mathrm{ukp}$ ), które musi spełniać taki kandydat, ale ujęte w sposób negatywny:

1. nie pozostaje w stosunku pracy ze spółką ani nie świadczy pracy lub usług na jej rzecz na podstawie innego stosunku prawnego, co nie dotyczy wszakże osób wybranych do rady nadzorczej przez pracowników (co wynika z art. 19 ust. 1 pkt 2);

2. nie posiada akcji w spółce zależnej, z wyjątkiem akcji dopuszczonych do obrotu na rynku regulowanym, ani też nie pozostaje $\mathrm{z}$ tą spółką $\mathrm{w}$ stosunku pracy, ani nie świadczy pracy lub usług na jej rzecz na podstawie innego stosunku prawnego (co wynika z art. 19 ust. 1 pkt 3 i 4);

3. nie wykonuje zajęć, które pozostawałyby w sprzeczności z jego obowiązkami jako członka rady nadzorczej albo mogłyby wywołać podejrzenie o stronniczość lub interesowność bądź rodzić konflikt interesów wobec działalności spółki (co wynika z art. 19 ust. 1 pkt 5).

5.6. W końcowym punkcie tego wyliczenia (art. 19 ust. 1 pkt 6) znajduje się klauzula, zgodnie z którą kandydat na członka rady nadzorczej musi spełniać warunki (przede wszystkim w postaci sprecyzowanych zakazów) określone w odrębnych przepisach, co w szczególności odnosi się do takich aktów prawnych, jak: 1. ksh:

a) zakaz zasiadania w organach zarządzających lub sprawowania samodzielnych, istotnych dla funkcjonowania spółki, ról — między innymi prokurenta, adwokata, radcy prawnego, głównego księgowego, kierownika oddziału lub zakładu (w spółce z o.o. — art. 214; w spółce akcyjnej — art. 387),

b) skazanie prawomocnym wyrokiem za przestępstwa określone w przepisach kilku rozdziałów kodeksu karnego (art. 18);

2. samorządowe ustawy ustrojowe:

a) zakaz sprawowania określonych funkcji w jst — radnego, organu wykonawczego lub członka takiego organu, sekretarza, skarbnika, a także innych, kluczowych dla funkcjonowania jst, stanowisk, wymienionych w art. 24f ust. 2 usg, 25b ust. 3 usp i art. $27 \mathrm{~b}$ ust. 3 usw, który to zakaz obejmuje także małżonków osób sprawujących te funkcje;

3. ustawa o ograniczeniu prowadzenia działalności gospodarczej przez osoby pełniące funkcje publiczne ${ }^{24}$ :

a) zakaz zajmowania stanowisk lub pełnienia funkcji określonych w art. 1-2;

23 Rozporządzenie Prezesa Rady Ministrów z dnia 22 lutego 2017 r. w sprawie egzaminu dla kandydatów na członków organów nadzorczych (Dz.U. poz. 217).

24 Ustawa z dnia 21 sierpnia 1997 r. (tekst jedn. Dz.U. z 2017 r. poz. 1393). 
4. ustawa o wynagradzaniu osób kierujących niektórymi podmiotami prawnymi ${ }^{25}$ :

a) zakaz bycia członkiem rady nadzorczej w więcej niż jednej spółce (art. 4).

5.7. Porównanie przepisów obowiązujących przed uchwaleniem uzzmp $z$ brzmieniem tej ustawy wskazuje, że wymogi stawiane kandydatom na członków rad nadzorczych zostały tylko w niewielkim stopniu zmienione i zaostrzone, co odnosi się w szczególności do zakresu przedmiotowego wymaganej wiedzy na egzaminie. Najistotniejszym novum jest wprowadzenie wymogu posiadania pięcioletniego okresu zatrudnienia lub wykonywania działalności gospodarczej na własny rachunek. Nie wydaje się jednak, by stanowiło to za wysoko zawieszoną poprzeczkę, jeżeli zważy się, że przy wykonywaniu zadań określonych przez ksh dla rady nadzorczej niesłychanie ważne, oprócz posiadanej przez jej członka wiedzy, jest doświadczenie, które nabywa się z czasem, pracując zawodowo. Jednocześnie rozszerzona została lista tych osiągnięć kandydata, które prowadzą do zwolnienia go ze zdawania egzaminu przed specjalną komisją. Oprócz poprzednio uznawanych stopni naukowych czy wykonywania określonego zawodu na ich listę wprowadzono uzyskanie dyplomu MBA i jednego z międzynarodowo akceptowanych certyfikatów. To rozszerzenie na pewno należy uznać za w pełni zasadne, choć niewątpliwie ma ono najistotniejsze znaczenie dla członków rad nadzorczych spółek Skarbu Państwa.

6.1. Z punktu widzenia jednostek samorządu terytorialnego wprowadzenie nowej regulacji prawnej dotyczącej rady nadzorczej wymaga komentarza zwłaszcza w dwóch punktach. Pierwszy z nich — natury jurydycznej — to kwestia zakresu zastosowania przepisów tej ustawy. W art. 10a ust. 5 ugk w odesłaniu do uzzmp wprawdzie wyraźnie przesądzono, że kandydaci do rad nie będą uzyskiwać opinii Rady do spraw spółek z udziałem Skarbu Państwa i państwowych osób prawnych (co jest w pełni zrozumiałe), to jednak wskazano jedynie art. 19 ust. 1 jako znajdujący zastosowanie do spółek komunalnych. A co z pozostałymi fragmentami (ustępami) tego przepisu i innymi artykułami odnoszącymi się do kandydatów na członków rady nadzorczej? Literalna wykładnia sugeruje odpowiedź jednoznaczną — pozostałe przepisy nie znajdują zastosowania. Gdyby bowiem ustawodawca chciał je uwzględnić, ich oznaczenie zamieściłby obok ust. 1. Takie rozumowanie prowadziłoby jednak do niezrozumiałego zróżnicowania wymogów wobec kandydatów do rad nadzorczych, a w konsekwencji — do zupełnie nieakceptowalnych rezultatów ${ }^{26}$.

25 Ustawa z dnia 3 marca 2000 r. (tekst jedn. Dz.U. z 2017 r. poz. 1222).

26 Podobne, choć nie do końca konsekwentne (zob. następny przypis), stanowisko zajmują C. Banasiński, K. Jaroszyński, op. cit., s. 183 n. 
Czy, tylko tytułem przykładu, pracownicy spółki komunalnej winni być pozbawieni prawa do wskazania członka rady nadzorczej (a to uprawnienie daje im art. 19 ust. 2 w kontekście brzmienia art. 19 ust. 1 pkt 2), wyłącznie dlatego że ustawodawca nie wymienił ust. 2 jako znajdującego zastosowanie do spółek samorządowych? Dlatego w procesie wykładni przepisów nowelizujących ugk należy posłużyć się też regułami wykładni funkcjonalnej odwołującej się do celu wprowadzanych rozwiązań. To oznacza, że wymogi ustanowione w dalszych ustępach art. 19 należy poddać ocenie z punktu widzenia ich adekwatności do sfery samorządowej. Nie ulega zatem wątpliwości, że do spółek komunalnych znajdzie zastosowanie wspomniany ust. 2, ale także ust. 3, w którym stwierdza się, że nie jest przeszkodą w kandydowaniu do rady nadzorczej fakt zasiadania w takiej radzie w spółce zależnej (w kontekście ograniczenia z ust. 1 pkt 4) czy ust. 5 wprowadzający dodatkowe, poza wskazanymi w ust. 1 pkt 2-5, okoliczności, zgrupowane w trzy kategorie, uniemożliwiające kandydowanie do rady (czyli też ujęte od strony negatywnej) osobie, która:

- pełni funkcję społecznego współpracownika albo jest zatrudniona w biurze poselskim, senatorskim, poselsko-senatorskim lub biurze posła do Parlamentu Europejskiego na podstawie umowy o pracę lub świadczy pracę na podstawie umowy zlecenia lub innej umowy o podobnym charakterze;

- wchodzi w skład organu partii politycznej reprezentującego partię polityczną na zewnątrz oraz uprawnionego do zaciągania zobowiązań;

- jest zatrudniona przez partię polityczną na podstawie umowy o pracę lub świadczy pracę na podstawie umowy zlecenia lub innej umowy o podobnym charakterze.

Nie ma najmniejszych powodów, aby te zakazy nie działały w sektorze samorządowym ${ }^{27}$. Należy wręcz uznać ten kierunek rozwiązań za szczególnie istotny w tej sferze. Trudno też byłoby znaleźć przyczyny, dla których nie znalazłby zastosowania przepis art. 19 ust. 6, w myśl którego „w przypadku gdy członek organu nadzorczego nie spełnia wymogów określonych w ust. 1-5, organ właściwy do jego odwołania niezwłocznie podejmuje działania mające na celu odwołanie członka organu nadzorczego".

6.2. Należy tu natomiast podnieść trzy kwestie natury praktycznej, odnoszące się do konsekwencji wprowadzonych zmian. Po pierwsze, niewątpliwie wymogiem o wyższym stopniu trudności w jego spełnieniu jest zdanie egzaminu przed specjalną komisją (art. 19 ust. 1 pkt 1 lit. j). W istotny sposób został bowiem poszerzony zakres wymaganej na nim wiedzy. O ile w rozporządzeniu, przytoczonym w przypisie 18, wyliczono, co do zasady, pewne grupy zagadnień omawianych w trakcie szkoleń przygotowujących do egzaminu (choć nieobowiązkowych), a w konsekwencji - obowiązujących na nim (na przykład tworzenie, funkcjono-

27 Inaczej, choć bez bliższego uzasadnienia C. Banasiński, K. Jaroszyński, op. cit., s. 184. Zob. też G. Góreczny, op. cit., s. 63 n. 
wanie i likwidacja spółek handlowych czy kompetencje organów tych spółek albo stosunki cywilnoprawne w obrocie gospodarczym), o tyle w obecnie obowiązujących przepisach, już wyraźnie odnoszących się do egzaminu, wymienione są całe gałęzie prawa (między innymi prawo gospodarcze prywatne, prawo gospodarcze publiczne, prawo rynku kapitałowego, prawo gospodarcze UE). Po drugie, kategorię osób mogących kandydować do rad nadzorczych zawęża wymóg — niemający wyjątków - posiadania wyższego wykształcenia, który — zwłaszcza w małych spółkach gminnych w odniesieniu do reprezentantów załogi — często nie był spełniony (było to możliwe na podstawie $\S 3$ rozporządzenia, o którym mowa w przypisie 18). Po trzecie - ograniczenia, o których mowa w art. 19 ust. 1 pkt 1, 2 i 4, nie dotyczą osób wybranych do organu nadzorczego przez pracowników (art. 19 ust. 2).

7.1. Odrębnego komentarza wymaga zagadnienie powoływania i posiadanych kwalifikacji członków organu zarządzającego spółki, czyli jej zarządu. Nie zmienia się tryb powoływania członków zarządu. O ile w stosunku do spółek z udziałem Skarbu Państwa obowiązują przepisy ksh (art. $201 \S 4$ traktujący o spółce z o.o., w której członków zarządu powołują i odwołują wspólnicy, chyba że umowa spółki stanowi inaczej, oraz art. 368 § 4 dotyczący spółki akcyjnej, w myśl którego członków zarządu powołuje i odwołuje rada nadzorcza, o ile statut nie stanowi inaczej), w tym zakresie niezmodyfikowane w uzzmp, o tyle w ugk w art. 10a ust. 6 , w jego brzmieniu niezmienionym $\mathrm{w}$ omawianej nowelizacji, przesądza się, że członków zarządu spółek z udziałem jst powołuje i odwołuje rada nadzorcza. Treść tego przepisu nie budzi żadnych wątpliwości zarówno w doktrynie ${ }^{28}$, jak i w orzecznictwie ${ }^{29}$. Ma on charakter bezwzględnie obowiązujący i dotyczy wszystkich spółek z udziałem jst — nie tylko jednoosobowych, lecz także z udziałem większościowym i mniejszościowym.

7.2. W komentowanej nowelizacji zasadniczo zmieni się natomiast wymagania, jakie winni spełniać kandydaci na członków zarządu. Do momentu wejścia jej w życie w przepisach ugk nie było jakiegokolwiek unormowania tej kwestii. Obowiązywały zatem ogólne regulacje odnoszące się do członków zarządu zawarte $w$ ksh i innych ustawach (między innymi wskazanych w punkcie 5.6). Obecnie problem ten znalazł swoje unormowanie w nowym ust. 7 art. 10a, zgodnie z którym

Podmiot reprezentujący JST lub komunalną osobę prawną w zakresie wykonywania praw $\mathrm{z}$ akcji przysługujących tym podmiotom, jest obowiązany podejmować działania mające na celu określenie, w drodze uchwały walnego zgromadzenia lub w statucie spółki z udziałem JST, wymogów, jakie musi spełniać kandydat na członka organu zarządzającego, określonych w art. 22 uzzmp.

28 Zob. M. Szydło, op. cit., s. 443 n.; W. Gonet, op. cit., s. 87 n.; J.J. Zięty, op. cit., s. 135 n.; C. Banasiński, K. Jaroszyński, op. cit., s. 184 n.

29 Zob. wyrok SA w Warszawie z dnia 25 kwietnia 2007 r., sygn. VI ACa 1364/06, LEX nr 682871 . 
W artykule tym sformułowane zostały wymagania wobec kandydatów do zarządu spółki z udziałem Skarbu Państwa, które są albo powtórzeniem wymogów stawianych kandydatom do rad nadzorczych wskazanych w art. 19 ust. 1 pkt 1 in principio (wykształcenie i ogólny staż pracy — art. 22 pkt 1 lit. a-b), albo nowymi przesłankami, co przede wszystkim odnosi się do warunku posiadania co najmniej trzyletniego doświadczenia na stanowiskach kierowniczych lub samodzielnych albo wynikającego z prowadzenia działalności gospodarczej na własny rachunek (art. 22 pkt 1 lit. c). Ponadto ogólnie ujęty został wymóg (art. 22 pkt 1 lit. d) spełnienia innych niż wymienione w lit. a-c warunków określonych w przepisach odrębnych, a w szczególności nienaruszania ograniczeń lub zakazów zajmowania stanowiska członka organu zarządzającego w spółkach handlowych.

Jednocześnie art. 22 pkt 2 zawiera zakaz zajmowania funkcji w zarządzie przez osobę, która spełnia jeden z warunków wskazanych w art. 19 ust. 5 (pkt 6.1), albo pełni funkcję z wyboru w zakładowej organizacji związkowej lub zakładowej organizacji związkowej spółki z grupy kapitałowej (art. 22 pkt 2 lit. d). Ostatni wymóg, budzący najwięcej kontrowersji interpretacyjnych, został ujęty w postaci klauzuli generalnej (art. 22 pkt 2 lit. e) i sprowadza się do stwierdzenia, że członkiem organu zarządzającego nie może być osoba, której ,aktywność społeczna lub zarobkowa rodzi konflikt interesów wobec działalności spółki”.

Niewątpliwie tego typu sformułowanie, tak ogólne i nieprecyzyjne (jak każda klauzula generalna), będzie musiało być przedmiotem zarówno doktrynalnej dyskusji, jak i werdyktu judykatury. Tylko w pewnym zakresie korzystać będzie można $\mathrm{z}$ dorobku wypracowanego na gruncie podobnych przepisów, mówiących o sprzeczności interesów członka zarządu i spółki, znajdujących się w ksh (dla spółki z o.o. — art. 209; dla spółki akcyjnej — art. 377) ${ }^{30}$.

7.3. W art. 10a ust. 7, konstrukcyjnie będącym powieleniem ust. 5, pojawiły się zbliżone sformułowania odnoszące się - po pierwsze — do organu kierującego spółką, nazwanego organem zarządzającym (w ust. 5 mowa była o organie nadzorczym), choć w wypadku sektora komunalnego chodzi wyłącznie o zarząd spółki, co wynika bezpośrednio z ust. 6 tego artykułu (inne postaci takiego organu są wykluczone, jak na przykład rada administrująca znana spółce europejskiej — art. 2 pkt 5 uzzmp), i - po drugie — do zakresu zastosowania tego przepisu ograniczonego do spółek akcyjnych (identyczne ujęcie zawarte jest w ust. 5), kiedy nie ma żadnych wątpliwości, że winien on odnosić się także do spółek z o.o. Dlatego w pełni aktualne pozostają w tej materii wywody zamieszczone w punkcie 5.3 niniejszego opracowania.

Podobnie należy zinterpretować sformułowanie mówiące o uchwałach walnego zgromadzenia lub statucie spółki. Reguły wykładni językowej nie pozostawiają

30 Zob. zwłaszcza A. Szajkowski, M. Tarska, [w:] Kodeks spółek handlowych, t. 2. Spótka z ograniczona odpowiedzialnościa, Warszawa 2014, s. 500 n.; oraz A. Szajkowski, M. Tarska, [w:] Kodeks spółek handlowych, t. 3. Spółka akcyjna, Warszawa 2013, s. 663 n. 
wątpliwości, że mowa jest w tym przepisie o spółce akcyjnej, gdyż w ksh te terminy właśnie w stosunku do niej są używane. Przyczyna takiego ujęcia wynika ze wspomnianego powielenia konstrukcji art. 22 in principio uzzmp, który należy wszakże czytać przy uwzględnieniu art. 2 pkt 3-4, w myśl których przez statut rozumie się też umowę spółki, a przez walne zgromadzenie - zgromadzenie wspólników (są to terminy właściwe spółce z o.o.). Również w tym zakresie należy odwołać się do uwag zawartych w punkcie 5.3.

7.4. Do przeanalizowania pozostaje jednak kwestia rozumienia tego fragmentu ust. 7 art. 10a, w którym mowa jest o obowiązku podejmowania przez podmiot reprezentujący jst (będzie to organ wykonawczy gminy — wójt, burmistrz, prezydent miasta, a w powiatach i województwach najczęściej przewodniczący zarządu - starosta lub marszałek województwa) działań mających na celu określenie, w drodze uchwały walnego zgromadzenia lub w statucie spółki, wymogów, jakie musi spełniać kandydat na członka zarządu. Sformułowanie tego obowiązku oznacza, że ustawodawca nie formułuje tych wymogów jako obowiązujących $\mathrm{z}$ mocy prawa $^{31}$, lecz obliguje przedstawiciela jst $\mathrm{w}$ trakcie procedury tworzenia albo dokonywania zmiany statutu lub umowy spółki do proponowania, by w ich tekście znajdowały się postanowienia dotyczące warunków, jakie musi spełniać kandydat do zarządu, a winny one odpowiadać treściowo właściwym przepisom uzzmp. Tym samym oczekuje się od tegoż reprezentanta dochowania najwyższej staranności przy dokonywaniu tych czynności.

Problem niezrealizowania tego obowiązku nie może powstać, gdy jst jest jedynym albo większościowym wspólnikiem, albowiem tylko od jego przedstawiciela zależy wprowadzenie do tekstu statutu czy umowy odpowiednich postanowień. I wprawdzie w ustawie nie formułuje się konsekwencji niewywiązania się z tego obowiązku i kreowania szczególnej postaci odpowiedzialności, to jednak należy potraktować takie zaniechanie za nieprzestrzeganie obowiązującego prawa, prowadzące do możliwości powstania odpowiedzialności z tego tytułu; tak jak zgłoszenie do rady nadzorczej kandydata niespełniającego wymogów określonych w art. 19 (zob. punkty 5.4-5.6). Inaczej przedstawia się sytuacja, gdy jst jest akcjonariuszem czy udziałowcem mniejszościowym i podmiot ją reprezentujący nie jest w stanie ,przeforsować” postanowień uwzględniających unormowanie art. 22 uzzmp. Wtedy taka osoba może być oceniana wyłącznie w kategoriach dołożenia, uznanej za właściwą dla danej sytuacji, staranności.

8. Wprowadzone do ugk zmiany, choć w zamyśle ustawodawcy miały jedynie, jak się wydaje, doprowadzić do przeniesienia na grunt komunalnych spółek prawa handlowego zmodyfikowanych zasad dotyczących wymogów, jakie winni spełnić kandydaci do rady nadzorczej i zarządu, mają wszakże znacznie szerszy zakres. Podstawą takiej konstatacji jest sposób skonstruowania i sformułowania obu naj-

31 Tak słusznie C. Banasiński, K. Jaroszyński, op. cit., s. 185 n. 
ważniejszych przepisów art. 10a, czyli ust. 5 i 7, w swej konstrukcji będących powtórzeniem art. 19 i 22 uzzmp. Zastąpiono w nich bowiem pojęcie „państwowa osoba prawna” terminem „komunalna osoba prawna”, będąca akcjonariuszem lub udziałowcem spółki komunalnej. To pojęcie w dotychczasowym brzmieniu tego artykułu nie występowało. Taki zabieg wymusza zatem postawienie istotnych pytań o przyczyny, jurydyczny sens i konsekwencje wprowadzenia tego określenia.

Nasuwających się wątpliwości jest wiele. Wystarczy postawić kilka pytań. Po pierwsze, jakie osoby prawne można określić mianem „komunalnej osoby prawnej"? Jakże bogata literatura i orzecznictwo na ten temat powstało w ciągu ostatnich 20 lat $^{32}$. Drugie pytanie brzmi: czy w przepisach innych ustępów art. 10a też chodzi o takie spółki, w których wspólnikiem jest komunalna osoba prawna? Trzecie: czy w art. 10b z rozmysłem rezygnuje się z użycia tego terminu, pozostając jedynie przy pojęciu jst? Udzieleniu odpowiedzi na te i inne nasuwające się pytania, wymagających jednak szerszych rozważań, warto zatem poświęcić odrębne opracowanie.

\title{
THE IMPACT OF NEW RULES OF THE MANAGEMENT OF STATE PROPERTY ON THE SHAPE OF THE SUPERVISORY BOARD AND THE BOARD OF THE MUNICIPAL COMPANY
}

\author{
Summary
}

The act on the management of the state property adopted in 2016 significantly transformed the entire system of management of state property, including its functional and structural-organisational aspects. As part of this reform, some provisions of the municipal economy act were also amended, which is understandable given affiliation of both types of property (state and municipal) to one category of public property. This article answers the question - what are the consequences for the self-government sector and economic agents operating within it (entrepreneurs acting on the basis of municipal property) of the changes made relating to the status, composition, appointment and operation of the supervisory board and board of directors of municipal company.

Keywords: state property, municipal property, municipal economy, municipal company, supervisory board, board of directors

${ }^{32} \mathrm{Z}$ ogromnej w tym zakresie literatury zob. J. Jagoda, [w:] Ustawa o samorzadzie gminnym. Komentarz, red. B. Dolnicki, Warszawa 2016, s. 871 n.; J. Dominowska, [w:] Ustawa o samorzadzie gminnym. Komentarz, red. R. Hauser, Z. Niewiadomski, Warszawa 2011, s. 460 n.; K. Bandarzewski, [w:] Ustawa o samorzadzie gminnym. Komentarz, red. P. Chmielnicki, Warszawa 2013, s. 650 n.; J. Jagoda, [w:] Ustawa o samorządzie województwa. Komentarz, red. B. Dolnicki, Warszawa 2012, s. 472 n., i wskazane w tych publikacjach literatura oraz orzecznictwo. 


\section{BIBLIOGRAFIA}

Banasiński C., Jaroszyński K., Ustawa o gospodarce komunalnej. Komentarz, Warszawa 2017.

Banasiński C., Kulesza M., Ustawa o gospodarce komunalnej. Komentarz, Warszawa 2002.

Doliwa A., Osobowość prawna jednostek samorządu terytorialnego, Warszawa 2012.

Gonet W., Ustawa o gospodarce komunalnej. Komentarz. Wzory umów i regulaminów, Warszawa 2010.

Góreczny G., Rada nadzorcza w spótkach komunalnych — zarys problematyki, „Samorząd Terytorialny" 2010, $\mathrm{nr} 11$.

Kodeks spótek handlowych, t. 2. Spółka z ograniczona odpowiedzialnościa, Warszawa 2014.

Kodeks spółek handlowych, t. 3. Spótka akcyjna, Warszawa 2013.

System Prawa Administracyjnego, t. 8A. J. Grabowski, L. Kieres, A. Walaszek-Pyzioł, Publiczne prawo gospodarcze, Warszawa 2013.

System Prawa Prywatnego, t. 3. Prawo rzeczowe, red. E. Gniewek, Warszawa 2013.

Szydło M., Ustawa o gospodarce komunalnej. Komentarz, Warszawa 2008.

Ustawa o samorzadzie gminnym. Komentarz, red. B. Dolnicki, Warszawa 2016.

Ustawa o samorzadzie gminnym. Komentarz, red. P. Chmielnicki, Warszawa 2013.

Ustawa o samorzadzie gminnym. Komentarz, red. R. Hauser, Z. Niewiadomski, Warszawa 2011.

Ustawa o samorządzie województwa. Komentarz, red. B. Dolnicki, Warszawa 2012.

Zięty J.J., Ustawa o gospodarce komunalnej. Komentarz, Warszawa 2012. 